\title{
The Effect of Different Supplements to in vitro Maturation Medium on Nuclear Maturation Rate of Buffalo Oocytes Assessed based on Stage of Nucleus
}

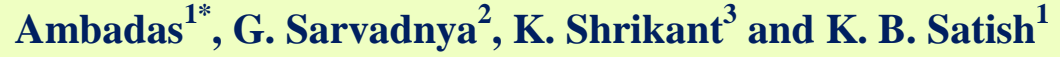 \\ ${ }^{1}$ Department of Veterinary Physiology and Biochemistry, Veterinary College, Bidar, India \\ ${ }^{2}$ Veterinary Dispensary Donagapur Tq Bhalki Dist, Bidar, India \\ ${ }^{3}$ Department of Veterinary Physiology and Biochemistry, Veterinary College, Bidar, India \\ *Corresponding author
}

\section{A B S T R A C T}

For comparing the efficacy of serum gonadotropin @50 and 100IU/ml, estrodiol-

Keywords

Maturation medium, Nuclear maturation rate, Buffalo oocytes

Article Info

Accepted:

15 January 2020

Available Online:

10 February 2020
$17 \beta @ 0.5$ and 1 $\mu \mathrm{g} / \mathrm{ml}$, EBS @5 and 10\% and BFF@5 and 10\% supplementation on in vitro nuclear maturation rate of buffalo oocytes. Ovaries were collected from buffaloes slaughtered at local abattoir. Oocytes were aspirated and good and excellent quality oocytes were matured in basic maturation media TCM199 supplementing above mentioned supplements separately. The recovery rate of culturable oocytes was $85.33 \%$. The nuclear maturation rate (NMR) was highest in the oocytes supplemented with 10\% EBS and lowest with estradiol-17 $\beta @ 1 \mu \mathrm{g} / \mathrm{ml}$. The statistical analysis revealed that NMR was significantly $(\mathrm{p} \leq 0.05)$ higher in the group supplemented with $10 \%$ EBS as compared to all other groups. It can be concluded that the supplementation of EBS to IVM medium has positive effect on nuclear maturation rate. Overall results suggest that serum gonadotrophin is less effective than EBS but more effective than estradiol-17 $\beta$ and BFF. Buffalo follicular fluid is more effective than estradiol-17 $\beta$ but less effective than EBS and serum gonodotrophin. Estrodiol-17 $\beta$ is the least effective supplement to increase in vitro nuclear maturation rate of buffalo oocytes.

\section{Introduction}

The buffalo forms the backbone of India's dairy industry and is considered as the 'bearer cheque' of the rural flock and India's milking machine (Balain, 1999). As per the $19^{\text {th }}$ livestock census India has around 108.7 million of buffalo population and constitutes around $21.23 \%$ of total livestock population. Buffalo population of Karnataka is 33.06 lakhs. Buffalo contributes 51\% (132430 tonnes) of total nation's milk production and around 1103.85 tonnes of meat production of total nation's meat production (Department of 
Animal Husbandry Dairying and Fisheries, ministry of agriculture, New Delhi,2014).

The buffalo is the predominant domestic animal for milk and meat production. On average, buffalo is four times as productive as an average indigenous cow in India. India has world's best buffalo dairy breeds and provides superior buffalo germplasm to several countries of the world (Kaikini, 1992).The domestic water buffalo plays a key role in milk production in many Asian countries including India, and they are able to withstand the adverse environmental conditions of the tropics. However the buffalo are traditionally considered to have a low reproductive efficiency (Pankaj, 2015). The low reproductive efficiency in female buffalo can be attributed to delayed puberty, higher age at calving, long postpartum anoestrus period, long calving interval, lack of overt sign of heat, and low conception rate. In addition, female buffaloes have few primordial follicles and a high rate of follicular atresia. These factors are responsible for driving a large number of buffaloes to slaughter house either prior to maturity or after calving, which has resulted in enormous loss of genetic resources and significant decline in their number in recent years. Thus there is a need to improve reproductive performances of buffaloes.

In vitro maturation (IVM) of oocytes and in vitro fertilization (IVF), in vitro culture of embryos and embryo transfer technology appear to be useful techniques for the improvement of reproductive efficiency of buffaloes (Uma, 1997). Embryo transfer technology has made rapid strides in dairy cattle industry and has become viable commercially in some of advanced countries. Therefore, the emphasis has now shifted to in vitro embryo production (IVEP) as it can salvage the genetic potential from infertile female and can yield large number of embryos (Kumar and Anand, 2012).Ovaries of the slaughtered animals are the cheapest and the most abundant source of primary oocytes for large scale production of embryos through in vitro maturation (IVM) and in vitro fertilization (IVF) (Agrawal et al., 1995).

In vitro maturation (IVM) is the one of the essential step and starting point for lot of biotechnological applications in animals like in vitro fertilization (IVF), cloning, transgenic animal production and embryonic stem cell research. Oocytes maturation is the process of complex changes in the protein phosphorylation which transform the primary oocytes in to mature secondary oocytes. Maturation of the oocytes included two aspects viz., nuclear and cytoplasmic maturation. The nucleus and the cytoplasm of the oocytes undergo many changes during maturation, making it receptive to fertilization and competent to support embryonic development (Tomek et al., 2002).

Several workers have studied different aspects of IVM in mammalian oocytes. In most of the studies revealed that media designed originally for cell culture, are not capable of supporting high levels of oocytes maturation and, therefore, are commonly supplemented with sera and hormones, growth factors and antioxidants to improve the maturation rates at high level (Kumar and Anand, 2012). The maturation medium with the selection of protein supplements, hormones for IVM play an important role in subsequent IVF and in vitro development.

The oocytes maturation process involves the activation and inhibition of enzymes, hormones and growth factors, which results in nuclear and cytoplasmic maturation (Gilchrist et al., 2007). Nuclear maturation occurs spontaneously, and mechanical removal of the oocytes from the follicle is capable of triggering the process, but cytoplasmic 
maturation occurs more gradually (Brevini et al., 2007). Hormones like luteinizing hormone $(\mathrm{LH})$, follicle stimulating hormone (FSH), estrogens are frequently used as additives in maturation media to enhance the quality of the maturation process.

The identification of substances capable of delaying the nuclear maturation time and thus allowing cytoplasmic and nuclear changes to occur synchronously has been the subject of several studies. Follicular fluid (FF), consisting of electrolytes, hormones, amino acids, growth factors, among other components, has been used as a natural substance for blocking the meiosis (Aguilar et al., 2001). Supplementation of serum in media had favourable effect on maturation. The serum contains a number of known growth factors that have an important role in the regulation of oocyte maturation, particularly via cumulus cells, it also prevents the hardening of the zona pellucida; moreover, the beneficial action of serum may be due to its antioxidant properties (Mahmoud and Nawito, 2003). Estrus buffalo serum (EBS), a rich source of hormones and growth factors, could be used to improve the developmental competence of buffalo oocytes culture in vitro (Abid et al., 2008).

An attempt to induce in vitro maturation can only be successful in conditions that are similar to those existing in vivo. Therefore, the biochemical composition of the oocyte culture media has great influence on the success rate of in vitro maturation. Since, under in vivo conditions the oocytes maturation is influenced by various steroid and gonadotropic hormones, it is necessary to supplement the steroid and hormones to the medium in order to sustain the growth and development of oocytes either by directly or through the hormone rich serum medium. Therefore the development of a suitable culture system and components of maturation media for in vitro maturation of oocytes is a major component of the in vitro embryo production procedures.

Perusal of literature indicates less number of works on optimizing the in vitro maturation of buffalo oocytes as compared to the other species. Considering all these points present study was designed to investigate the effect serum gonadotrophin, estradiol-17 $\beta$, estrous buffalo serum (EBS) and buffalo follicular fluid (BFF) supplementation on in vitro nuclear maturation rate.

\section{Materials and Methods}

All the media and chemicals were procured from Himedia Laboratories, Mumbai unless otherwise stated. Folligon ${ }^{\circledR}$ (Pregnant Mare Serum Gonadotrophin, 1000IU/vial) and Chorulon ${ }^{\circledR} \quad$ (Human Chorionic Gonadotrophin, 1500IU/vial) were purchased from Intervet International B.V., Boxmeer, Netherland. The disposable plastic wares used in this experiment were obtained either from Tarsons Products Private Limited, Kolkota or from Himedia Laboratories, Mumbai.

All the media were prepared by using sterile tissue culture grade water. All the working solutions/media excluding OCM were kept for at least $3-4 \mathrm{hr}$ in $\mathrm{CO}_{2}$ incubator at $38^{\circ} \mathrm{C}$, $5 \% \mathrm{CO}_{2}$ and $95 \%$ relative humidity for quenching before use. Prepared OCM was kept in BOD at $37^{\circ} \mathrm{C}$. The stocks of media were stored at $4^{\circ} \mathrm{C}$ and used within one month.

\section{Sterilization procedures}

Sterilization of all media was done by filtering through $0.2 \mu \mathrm{m}$ syringe driven filters. The glassware and micropipette tips were sterilized by autoclaving at $121^{\circ} \mathrm{C}$ for $30 \mathrm{~min}$. Fresh sterilized and disposable culture bottles, petridishes, tubes and syringe were used every 
time. All the equipments were exposed to UV light for 15 minutes before use. In order to avoid bacterial and fungal contamination all the procedure except the aspiration of oocytes, starting from oocyte searching to in vitro culture works and media preparation were carried out in highly sterile condition under laminar flow cabinet.

\section{Preparation of buffalo serum and estrous buffalo serum (EBS)}

The blood was collected from jugular vein of normal cycling buffaloes that are not in estrus as well as from the buffaloes that are in estrus for the separation of buffalo serum and estrus buffalo serum respectively. The collected blood was kept in slant position and allowed to clot, later blood was centrifuged at $3000 \mathrm{rpm}$ for $15 \mathrm{~min}$ for serum separation. The separated serum was heat inactivated at $56^{\circ} \mathrm{C}$ for 30 minutes, filtered through $0.45 \mu \mathrm{m}$ filter and stored at $-20^{\circ} \mathrm{C}$ in $2.0 \mathrm{ml}$ micro centrifuge tubes as aliquots for future use. Same batch of pooled serum was used for all the trials. The buffalo serum was used in the preparation of working oocyte collection medium (OCM) whereas EBS was used as supplement in T5 and T6 groups.

\section{Colection of buffalo follicular fluid (BFF)}

Ovaries were collected immediately after slaughter of buffaloes of unknown reproductive status at the local abattoir. The ovaries were maintained in a thermos flask containing warm $\left(35-37^{\circ} \mathrm{C}\right)$ normal saline $(0.9 \% \mathrm{NaCl})$ fortified with $50 \mu \mathrm{g} / \mathrm{ml}$ gentamycin sulphate (Gentalab). The ovaries were transported to the laboratory within $2 \mathrm{hrs}$ after slaughter of animals. At the laboratory, the buffalo ovaries obtained from the abattoir were rinsed thoroughly with fresh sterile normal saline supplemented with gentamycin @ 50 $\mu \mathrm{g} / \mathrm{ml}$ 5-6 times and final wash was done with Phosphate buffered saline (PBS).
Follicular fluid was aspirated from non atretic, surface follicles $(>3 \mathrm{~mm}$ diameter) of the ovaries using $5 \mathrm{ml}$ syringe attached with 18-gauge needle. The pooled follicular fluid was allowed to settle for $10 \mathrm{mins}$ and the supernatant was collected. The collected follicular fluid was sterilized by filtering through $0.22 \mu \mathrm{m}$ syringe driven filter and stored in sterile micro centrifuge tubes of $2.0 \mathrm{ml}$ capacity at $-20^{\circ} \mathrm{C}$ for subsequent use for IVM as supplement in T7 and T8 groups.

\section{Collection of ovaries and semen sample}

Buffalo ovaries were collected immediately after slaughter of the animals of unknown reproductive status at the local abattoir. The ovaries were maintained in a thermos flask containing warm $\left(35-37^{\circ} \mathrm{C}\right)$ normal saline $(0.9 \% \mathrm{NaCl})$ fortified with $50 \mu \mathrm{g} / \mathrm{ml}$ gentamycin sulphate (Gentalab). The ovaries were transported to the laboratory within $2 \mathrm{hrs}$ after slaughter of animals.

The frozen buffalo bull semen straws supplied by Department of Animal Husbandry and Veterinary Services, Government of Karnataka to the Department of Veterinary Gynaecology and Obstetrics, Veterinary College, Bidar were utilized for in vitro fertilization.

\section{Methods}

\section{Oocytes collection, processing and grading}

Ovaries were collected immediately after slaughter of adult female buffaloes of unknown reproductive status at the local abattoir. The ovaries were maintained in a thermos flask containing warm $\left(35-37^{\circ} \mathrm{C}\right)$ normal saline $(0.9 \% \mathrm{NaCl})$ fortified with $50 \mu \mathrm{g} / \mathrm{ml}$ gentamycin sulphate. The ovaries were transported to the laboratory within $2 \mathrm{hrs}$ after slaughter of animals. In the laboratory, ovaries were washed 6-7 times in warm 
normal saline solution $\left(37^{\circ} \mathrm{C}\right)$ fortified with antibiotic and final two washings with PBS. Washed ovaries were submerged in PBS solution in sterile beaker and were used for oocyte collection. Oocytes were aspirated from all visible non atretic follicles $(2-8 \mathrm{~mm}$ in diameter) by an 18gauge needle attached to $5 \mathrm{ml}$ sterile disposable syringe (Dispovan, India) containing $0.5 \mathrm{ml}$ oocyte collection media (OCM) (Appendix-I). The cumulus oocyte complexes (COC) along with follicular fluid was pooled into $50 \mathrm{ml}$ sterile plastic tube containing $1-2 \mathrm{ml} \mathrm{OCM}$ at $37^{\circ} \mathrm{C}$ and were allowed to settle for 10 minutes.

Finally the sediments were taken in large petridish $(90 \mathrm{~mm})$ and oocytes were searched under zoom stereo microscope (Motic, Germany). The cumulus oocyte complexes (COC) were isolated, evaluated and graded. Only excellent (>5 layers of cumulus cells and evenly granulated cytoplasm) and good (>3 layers of cumulus cells and evenly granulated cytoplasm) COC were collected and washed several times in OCM followed by maturation media (MM) (Appendix II). The recovery rate of oocyte was calculated by dividing the sum of excellent and good quality oocytes recovered with total number of ovaries aspirated.

Ooctye recovery rate $(\%)=$

Total no of excellent and good quality oocytes

Number of ovaries aspirated

\section{In vitro maturation of oocytes}

Graded oocytes were washed in respective maturation media for 4-5 times. After washing, 15-20 oocytes were cultured in 50 $\mu 1$ droplets of respective maturation media in $35 \mathrm{~mm}$ sterile petridish. The droplet was covered with warm, non toxic mineral oil and incubated at $38^{\circ} \mathrm{C}, 5 \% \quad \mathrm{CO}_{2}, 95 \%$ relative humidity for $24 \mathrm{hrs}$ in $\mathrm{CO}_{2}$ incubator (Nuaire, USA). The experiment was repeated 6 times for each group as replicates.

The selected oocytes were cultured in TCM 199 medium containing $10 \% \mathrm{FCS}, 0.3 \%$ BSA and $10 \mathrm{IU} / \mathrm{ml}$ of hCG with different supplements as shown in Table No 1.

\section{Assessment of nuclear maturation of oocytes}

After $24 \mathrm{~h}$ of culture in maturation medium, oocytes were denuded by treating with TCM199 containing $0.1 \%$ hyaluronidase and passing them through a fine pipette. Denuded oocytes were washed twice with WM $(2 \%$ FCS) and mounted on slides in a microdroplet (10-20 $\mu \mathrm{l})$ between 2 parallel lines of wax:vaseline (1:20). A cover slip was placed on the lines and pressed gently using a needle until it touched the microdroplet containing the oocytes. Gentle pressure was applied to anchor the oocytes between the slide and cover slip. Oocytes were fixed for $24 \mathrm{~h}$ in a mixture of acetic acid and alcohol at 1:3 ratios at room temperature. Then fixed oocytes were stained for $10 \mathrm{~min}$ with $1 \%(\mathrm{w} / \mathrm{v})$ orcein in $45 \%$ acetic acid. After 3-5min, destaining solution (acetic acid:distilled water:glycerol: $1: 3: 1)$ was passed thoroughly to remove excess stain, making sure that the oocytes were not washed away. The cover slip was sealed with DPX mountant and stained oocytes were examined under a light microscope $(400 \times)$ and phase contrast microscope to determine the stages of nuclear maturation, i.e. germinal vesicle $(\mathrm{GV})$ and germinal vesicle breakdown. Oocytes with a distinct nuclear membrane and no detection of chromatin material were categorized as GV stage. Germinal vesicle breakdown (GVBD) was detected by either deeply stained chromatin at the mitotic plate (M I) or deeply stained chromatin with the presence of 1 or 2 polar bodies (M II). Nuclear maturation was 
calculated by dividing number of GVBD (M-I and M-II stage) oocytes with total number of matured oocytes stained and expressed in percent nuclear maturation.

Nuclear maturation $(\%)=$

Number of GVBD+M-I and M-II stage oocytes $\times 100$

Total number of matured oocytes stained

\section{Results and Discussion}

\section{Nuclear maturation rate}

Nuclear maturation rate was assessed as GV, GVBD, MI and MII stages. Oocyte with a distinct nuclear membrane and no detection of chromatin material were categorized as $\mathrm{GV}$ stage. Germinal vesicle breakdown (GVBD) was detected by either deeply stained chromatin at the mitotic plate (M I) or deeply stained chromatin with the presence of 1 or 2 polar bodies (M II) (Plate 6; Table 4 and 5).

Out of 24 oocytes assessed for nuclear maturation in each group, mean percentage of oocytes in GV stage for serum gonadotrophin @ $50 \mathrm{IU} / \mathrm{ml}$, serum gonadotrophin @ 100 IU $/ \mathrm{ml}$, estradiol-17 $@ 0.5 \mu \mathrm{g} / \mathrm{ml}$, estradiol$17 \beta @ 1 \mu \mathrm{g} / \mathrm{ml}, 5 \%$ estrus buffalo serum, 10\% estrus buffalo serum, 5\% buffalo follicular fluid and $10 \%$ buffalo follicular fluid supplementation were $33.33 \pm 8.33$, $25.00 \pm 9.12, \quad 41.67 \pm 5.27, \quad 54.17 \pm 10.03$, $29.17 \pm 7.68, \quad 12.50 \pm 5.59, \quad 45.83 \pm 7.68$ and $41.67 \pm 5.27$ respectively. GVBD stage was observed in $8.33 \pm 5.27, \quad 29.17 \pm 7.68$, $20.83 \pm 7.68, \quad 12.50 \pm 5.59, \quad 8.33 \pm 5.27$, $20.83 \pm 7.68, \quad 12.50 \pm 5.59$ and $16.67 \pm 5.27$ percentage of oocytes respectively in $\mathrm{T} 1, \mathrm{~T} 2$, T3, T4, T5, T6, T7 and T8 groups. The percentage of oocytes reaching MI stage of nuclear maturation were $12.50 \pm 5.59$, $20.83 \pm 7.68, \quad 16.67 \pm 8.33, \quad 12.50 \pm 5.59$,
$25.00 \pm 9.12, \quad 25.00 \pm 6.45, \quad 8.83 \pm 5.27 \quad$ and $12.50 \pm 5.59$ in T1, T2, T3, T4, T5, T6, T7 and T8 groups respectively. The mean percentage values of oocytes showing MII stage with polar body were $45.83 \pm 7.68,25.00 \pm 6.45$, $20.83 \pm 7.68, \quad 20.83 \pm 7.68, \quad 37.50 \pm 10.70$, $41.67 \pm 5.17,33.33 \pm 5.27$ and $29.17 \pm 4.16$ for T1, T2, T3, T4, T5, T6, T7 and T8 groups respectively.

For the comparison among the groups, the nuclear maturation rate was assessed as the total number of oocytes showing GVBD, MI and MII with polar body stages. The mean percentage nuclear maturation rate in serum gonadotrophin @ $50 \mathrm{IU} / \mathrm{ml}, \quad$ serum gonadotrophin @100 IU/ml, estradiol-17

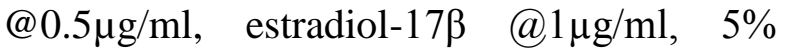
estrus buffalo serum, $10 \%$ estrus buffalo serum, 5\% buffalo follicular fluid and $10 \%$ buffalo follicular fluid supplemented groups were $66.66 \pm 8.33,75.00 \pm 9.12,58.33 \pm 5.27$, $45.83 \pm 10.03, \quad 70.83 \pm 7.68, \quad 87.50 \pm 5.59$, $54.16 \pm 7.68$ and $58.33 \pm 5.27$ respectively (Table 4; Plate 9).

The mean values of nuclear maturation rate was highest for the oocytes cultured in IVM medium supplemented with $10 \%$ estrus buffalo serum and the lowest nuclear maturation rate was observed with supplementation of estradiol-17 $@ @ 1 \mu \mathrm{g} / \mathrm{ml}$ among all the experimental groups. The statistical analysis of the data revealed that cytoplasmic maturation rate was significantly $(\mathrm{p} \leq 0.05)$ higher in the group supplemented with $10 \%$ estrus buffalo serum as compared to all other groups of the experiment. There was no significant $(\mathrm{p} \leq 0.05)$ difference in the nuclear maturation rate among the groups supplemented with serum gonadotrophin @50 $\mathrm{IU} / \mathrm{ml}$, serum gonadotrophin @ 100IU $/ \mathrm{ml}$, estradiol-17 $@ 0.5 \mu \mathrm{g} / \mathrm{ml}$, estradiol-17 $\beta$ $@ 1 \mu \mathrm{g} / \mathrm{ml}, 5 \%$ estrus buffalo serum, 5\% buffalo follicular fluid and $10 \%$ buffalo follicular fluid. 
The comparison of mean values of nuclear maturation rate between two different concentrations of each supplement suggested that there was no significant $(p \leq 0.05)$ difference between serum gonadotrophin @ 50IU/ml and @100IU/ml, estradiol-17 $\beta @$ $0.5 \mu \mathrm{g} / \mathrm{ml}$ and $@ 1 \mu \mathrm{g} / \mathrm{ml}, 5 \%$ and 10\% buffalo follicular fluid. Whereas, IVM medium supplemented with $10 \%$ estrus buffalo serum showed significantly $(\mathrm{p} \leq 0.05)$ higher nuclear maturation rate than that supplemented with $5 \%$ estrus buffalo serum.

In sexually matured females, after the leutinizing hormone surge, the fully grown oocytes in graffian follicles tends to initiate and complete the first meiotic division which leads to meiotic metaphase II. On the other hand, oocytes isolated mechanically from the follicles are found to resume meiosis spontaneously in vitro. Oocyte maturation is the process associated with the initiation of germinal vesicle breakdown and completion of first meiotic division and entering into second meiotic division and reaching metaphase II. Recent studies indicate that there are some growth factors which initiate the meiotic maturation in vitro. These growth factors are capable of promoting maturation of bovine cumulus oocyte complexes. Hormone and serum supplementations are also essential for promoting maturation of bovine oocytes complexes (Totey et al., 1992). In the present study serum gonadotrophin, estrodiol-17 $\beta$, estrous buffalo serum and buffalo follicular fluid supplementation are used to compare their efficacy on in vitro nuclear maturation of buffalo oocytes

\section{In vitro maturation}

\section{Serum gonadotropin}

Supplementation of serum gonadotrophin @ $100 \mathrm{IU} / \mathrm{ml}$ to IVM medium showed no significant effect in terms of nuclear maturation where as supplementation of the same@50IU/ml did not show much beneficial effects. Tsafriri et al., (2005) stated that in many mammalian species, gonadotrophins are found to stimulate cumulus cells to synthesize molecules able to drive germinal vesicle breakdown GVBD as meiosis- activating sterols. It is suggested that the presence of gonadotrophins in the maturation media increases the level of intracellular cAMP, the activity of the hyaluronic acid synthesis enzyme system and induced cumulus expansion complexes. The results of the present work are in agreement with the findings of several researchers in different mammalian species. Mattioli et al., (1991) concluded from their study that gonadotrophins accelerated and facilitated meiotic progression selectively improved cytoplasmic maturation in porcine oocytes which is required to promote the formation of a female pronucleus. Momena et al., (2010) reported that IVM of goat oocytes is influenced by the supplementation of gonadotrophin in TCM-199 medium. Farag et al., (2013) showed that the supplementation of gonadotrophin (PMSG-hCG) to culture media significantly $(P \quad<0.05)$ improved meiotic maturation rate of camel denuded oocytes than that cultured in hormone-free media. Elkhadrawy et al., (2014) examined maturation rate of buffalo oocytes in the medium supplemented with different doses of purified FSH. Their results indicated that the maturation rate of buffalo oocytes were significantly $(\mathrm{P}<0.001)$ higher in TCM-199 supplemented with $6.25,12.5$ and $25 \mu \mathrm{g} / \mathrm{ml}$ of purified FSH than the control and highest maturation rate obtained by addition of $25 \mu \mathrm{g} / \mathrm{ml}$ purified FSH.

\section{Estrodiol-17 $\beta$}

The mean values of nuclear maturation rate in the groups supplemented with estradiol-17 $\beta$ 
@ $0.5 \mu \mathrm{g} / \mathrm{ml}$ and $1 \mu \mathrm{g} / \mathrm{ml}$ concentration were $58.33 \pm 5.27$ and $45.83 \pm 10.03$ respectively. The supplementation of estradiol-17 $\beta$ @ $1 \mu \mathrm{g} / \mathrm{ml}$ showed the lowest nuclear maturation rate among all the experimental groups. This inhibitory effect of Estradiol-17 $\beta$ on oocyte maturation is observed by McGaughey (1977) in pigs, Eppig and Koide (1978) and Dianne and Tenney (1980) in mouse. Estradiol-17 $\beta$ inhibited the cAMPphosphordiesterase activity of mouse oocyte in a concentration-dependent manner (Kaji, 1987). This finding provides an explanation for the inhibitory effect of steroid hormones on germinal vesicle breakdown (GVBD) of mouse oocytes in vitro. Similar to the present results Tesarik et al., (1995) reported that in humans the addition of E2 to oocyte maturation medium did not produce any apparent effects on either germinal vesicle breakdown or further progression of meiosis, but it did increase the fertilization and cleavage rates of the in vitro matured oocytes. Beker et al., (2002) matured bovine oocytes in TCM199 in the presence of $1 \mu \mathrm{g} / \mathrm{ml}$ E2 with or without $0.05 \mathrm{IU} / \mathrm{ml}$ recombinant $\mathrm{hFSH}$. They concluded that supplementation of $1 \mu \mathrm{g} / \mathrm{ml}$ E2 to a serum free maturation medium negatively affects bovine oocyte nuclear maturation and subsequent embryo development and these negative effects of E2 could be attenuated in the presence of FSH. Anna et al., (2004) have also observed a significant decrease in the percentage of oocytes that reached MII stage when COCs of bovine oocytes were cultured in the presence of E2 or E2- BSA. Estadiol 17- $\beta$ supplementation also delayed or inhibited oocyte meiotic maturation, such as chromosome alignment on the metaphase plate and extrusion of the first polar body (Wataru et al., 2014).In contrast Fukui et al., (1982) have reported increased in vitro maturation rate of bovine oocytes in the presence of estrodiol in culture medium. Similarly, Zheng et al., (2007) have reported improved oocyte developmental competence in rhesus monkey oocytes when they were cultured in in vitro maturation medium supplemented with estradiol.

\section{Estrus buffalo serum}

the nuclear maturation rates in the groups supplemented with estrus buffalo serum @ $5 \%$ and $10 \%$ concentrations were $70.83 \pm 7.68$ and $87.50 \pm 5.59$ respectively. Among the eight experimental groups under study the mean values of nuclear maturation rate was highest in the oocytes cultured in IVM medium supplemented with $10 \%$ estrus buffalo serum. The beneficial effect of supplementation of estrus buffalo serum to IVM medium on oocyte maturation and subsequent better cleavage rate could be attributed to the fact that estrus buffalo serum contains various hormones like FSH, LH and E2. Biological role of estrus serum is to compensate for whatever essential elements are missing from the medium by serving as a reservoir for many of the beneficial components, such as different energy substrates, steroids, amino acids, fatty acids, vitamins and growth factors. Serum also serves as a protective compound against scavenging ions and small molecules secreted from the developing embryo. Samad et al., (1998) evaluated four types of serum supplements viz., estrus cow serum (ECS), estrus buffalo serum (EBS), pro estrus buffalo serum (PrBS) and post estrus buffalo serum (PtBS) added to TCM-199 for in vitro maturation of buffalo follicular oocytes. They recorded oocytes maturation rate of $80.00,82.08,78.77$ and $66.23 \%$ respectively and concluded significantly high maturation rate in EBS supplemented group followed by ECS, PrBS and PtBS supplemented groups. Suresh and Maurya (2000) observed the maturation rate of buffalo oocytes in TCM-199 containing foetal calf serum, bubaline estrus serum and buffalo calf serum and concluded that the supplementation 
of bubaline estrus serum can enhance the buffalo oocyte maturation in vitro. Anthony et al., (2013) examined the maturation capacity of buffalo, sheep and goat oocytes in the media containing sera of three different groups of buffaloes (regularly cycling, pregnant and repeat breeding). The oocytes maturation rate of buffalo oocytes cultured in media containing sera of the control group and regularly cycling group were not significantly different. However when oocytes cultured in the media containing sera of pregnant buffaloes the maturation rate were significantly declined. Further significant declined in maturation rate were observed when oocytes cultured in media containing sera of repeat breeding buffaloes.

\section{Buffalo follicular fluid}

The mean nuclear maturations in groups supplemented with buffalo follicular fluid @ $5 \%$ and $10 \%$ concentrations were $54.16 \pm 7.68$ and $58.33 \pm 5.27$ respectively. The nuclear maturation rate of oocytes supplemented with buffalo follicular fluid was significantly lower than that of estrus buffalo serum supplemented groups.

Table.1 Composition and supplements of the maturation media in different groups

\begin{tabular}{|c|c|c|}
\hline Groups & Supplements & Detailed Composition of maturation medium \\
\hline T1 & $\begin{array}{l}\text { Serum Gonadotrophin } \\
@ 50 \mathrm{IU} / \mathrm{ml}\end{array}$ & $\begin{array}{l}\text { TCM 199+10\% FCS+ 0.3\% BSA+ hCG } \\
@ 10 \mathrm{IU} / \mathrm{ml}+\text { serum gonadotrophin @ 50IU/ml }\end{array}$ \\
\hline $\mathbf{T 2}$ & $\begin{array}{l}\text { Serum Gonadotrophin } \\
\quad @ 100 \mathrm{IU} / \mathrm{ml}\end{array}$ & $\begin{array}{l}\text { TCM 199+10\% FCS+ 0.3\% BSA+ hCG } \\
\text { @ 10IU/ml + serum gonadotrophin @ 100IU/ml }\end{array}$ \\
\hline T3 & 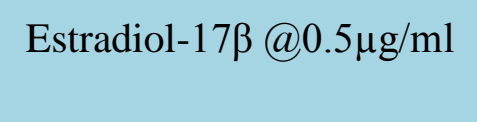 & $\begin{array}{l}\text { TCM 199+10\% FCS+ } 0.3 \% \text { BSA+ hCG } \\
@ 10 I U / m l+\text { Estradiol-17 } @ 0.5 \mu \mathrm{g} / \mathrm{ml}\end{array}$ \\
\hline T4 & 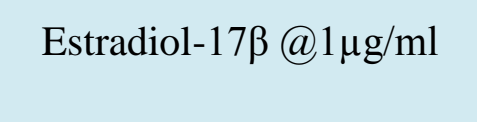 & $\begin{array}{l}\text { TCM 199+10\% FCS+ 0.3\% BSA+ hCG } \\
@ 10 I U / m l+\text { Estradiol-17 } @ 1 \mu \mathrm{g} / \mathrm{ml}\end{array}$ \\
\hline T5 & $5 \%$ Estrous buffalo serum & $\begin{array}{l}\text { TCM 199+10\% FCS+ } 0.3 \% \text { BSA+ hCG } \\
@ 10 I U / m l+5 \% \text { EBS }\end{array}$ \\
\hline T6 & $\begin{array}{l}10 \% \text { Estrous buffalo } \\
\text { serum }\end{array}$ & $\begin{array}{l}\text { TCM 199+10\% FCS+ 0.3\% BSA+ hCG } \\
@ 10 I U / m l+10 \% \mathrm{EBS}\end{array}$ \\
\hline T7 & $5 \%$ Buffalo follicular fluid & $\begin{array}{l}\text { TCM 199+10\% FCS+ } 0.3 \% \text { BSA+ hCG } \\
@ 10 I U / m l+5 \% \text { BFF }\end{array}$ \\
\hline T8 & $\begin{array}{l}10 \% \text { Buffalo follicular } \\
\text { fluid }\end{array}$ & $\begin{array}{l}\text { TCM 199+10\% FCS+ } 0.3 \% \text { BSA+ hCG } \\
@ 10 \mathrm{IU} / \mathrm{ml}+10 \% \mathrm{BFF}\end{array}$ \\
\hline
\end{tabular}


Table.4 The effect of different supplements to IVM medium on nuclear maturation rate (\%) of buffalo oocytes assessed based on stage of nucleus (Mean \pm SE)

\begin{tabular}{|c|c|c|c|c|c|c|c|}
\hline \multirow[t]{2}{*}{ Groups } & \multirow{2}{*}{$\begin{array}{l}\text { No. of } \\
\text { replicate }\end{array}$} & \multirow{2}{*}{$\begin{array}{c}\text { Number } \\
\text { of } \\
\text { oocytes } \\
\text { assessed }\end{array}$} & \multicolumn{4}{|c|}{ Stage of nuclear maturation } & \multirow{2}{*}{$\begin{array}{c}\text { Nuclear } \\
\text { maturation } \\
\text { rate }\end{array}$} \\
\hline & & & GV & GVBD & M-I & $\begin{array}{l}\text { M-II with } \\
\text { PB }\end{array}$ & \\
\hline $\mathbf{T 1}$ & 6 & 24 & $33.33 \pm 8.33$ & $8.33 \pm 5.27$ & $12.50 \pm 5.59$ & $45.83 \pm 7.68$ & $66.66 \pm 8.33^{\mathrm{bc}}(16)$ \\
\hline $\mathbf{T} 2$ & 6 & 24 & $25.00 \pm 9.12$ & $29.17 \pm 7.68$ & $20.83 \pm 7.68$ & $25.00 \pm 6.45$ & $75.00 \pm 9.12^{b}(18)$ \\
\hline T3 & 6 & 24 & $41.67 \pm 5.27$ & $20.83 \pm 7.68$ & $16.67 \pm 8.33$ & $20.83 \pm 7.68$ & $58.33 \pm 5.27^{\mathrm{bc}}(14)$ \\
\hline T4 & 6 & 24 & $54.17 \pm 10.03$ & $12.50 \pm 5.59$ & $12.50 \pm 5.59$ & $20.83 \pm 7.68$ & $45.83 \pm 10.03^{b c}(11)$ \\
\hline T5 & 6 & 24 & $29.17 \pm 7.68$ & $8.33 \pm 5.27$ & $25.00 \pm 9.12$ & $37.50 \pm 10.70$ & $70.83 \pm 7.68^{b c}(17)$ \\
\hline T6 & 6 & 24 & $12.50 \pm 5.59$ & $20.83 \pm 7.68$ & $25.00 \pm 6.45$ & $41.67 \pm 5.17$ & $87.50 \pm 5.59^{\mathrm{a}}(21)$ \\
\hline T7 & 6 & 24 & $45.83 \pm 7.68$ & $12.50 \pm 5.59$ & $8.83 \pm 5.27$ & $33.33 \pm 5.27$ & $54.16 \pm 7.68^{b c}(13)$ \\
\hline T8 & 6 & 24 & $41.67 \pm 5.27$ & $16.67 \pm 5.27$ & $12.50 \pm 5.59$ & $29.17 \pm 4.16$ & $58.33 \pm 5.27^{\mathrm{bc}}(14)$ \\
\hline
\end{tabular}

$a, b, c$ : Mean values of nuclear maturation rate with different superscripts differ significantly $(p \leq 0.05)$

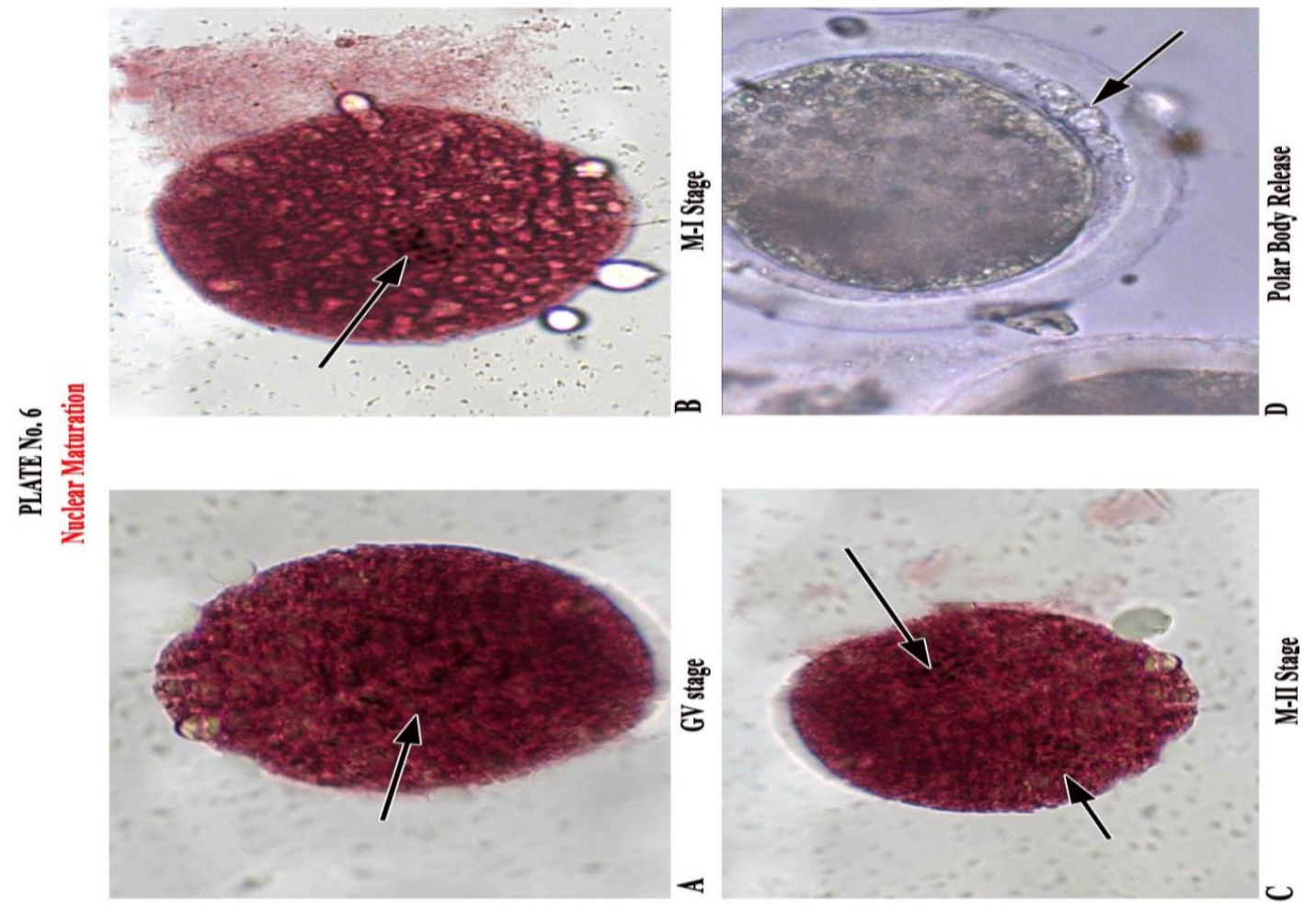




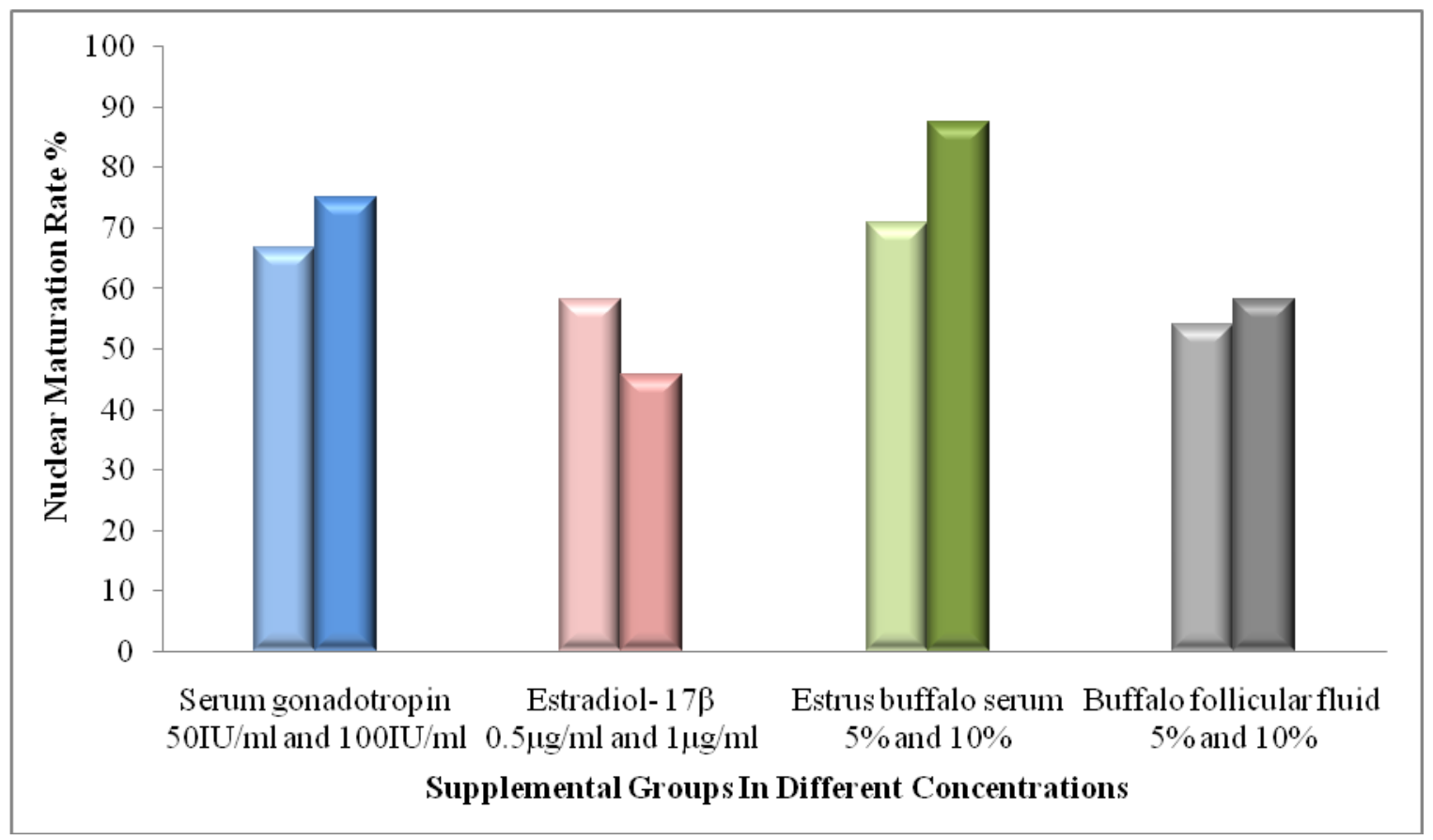

The observation of Stephen et al., (1984) that the follicular fluid transiently suppresses the germinal vesicle breakdown (GVBD) in mouse oocytes by elevating cAMP in the oocyte cumulus cell complex supports the present findings. Mammy et al., (2012) conducted in vitro maturation of buffalo oocytes in TCM 199 supplemented with $10 \%$ bovine follicular fluid (BFF), 5\% bovine serum albumin (BSA) or without supplementation. They concluded that supplementation $10 \% \mathrm{BFF}$ and 5\% BSA significantly increased the maturation rate than the control group. The discrepancy in the results of present experiment with others may be because of variations in the size and maturational status of the follicles from which the follicular fluid was collected. Because, Ayoub and Hunter (1993) collected bovine follicular fluid at different stages of the estrous cycle from small, medium, and large follicles. Follicular fluid from both small and medium follicles at estrus had the greatest ability to prevent germinal vesicle breakdown but became less potent at postestrus. Follicular fluid from large follicles at estrus had less ability to inhibit germinal vesicle breakdown than fluid from small and medium follicles. However, follicular fluid from large follicles had less germinal vesicle breakdown inhibiting activity at proestrus than follicular fluid from large follicles at late metestrus, early diestrus, and mid diestrus.

\section{References}

Abid Mehmood., Muhammad Anwar., Sayed Murtaza Hassan Andrabi., Muhammad Afzal. and Syed Muhammad Saqlan Naqvi., 2008. In vitro maturation and fertilization of bufflooocytes: the effect of recovery and maturation methods. Tur. $J$. Vet. Anim. Sci., 35(6): 381-386

Aguilar, J.J., Woods, G.L., Miragaya, M.H., Olsen, L.M. and Vanderwall, D.K., 2001. Effect of homologous preovulatory follicular fluid on in vitro maturation of equine cumulus-oocyte complexes. Theriogenology., 57: 745-58

Anna, R., Beker-Van Woudenberg., Helena, T.A., Van Tol., Bernard, A.J., Roelen., Ben Colenbrander. and Mart, M. Bevers., 2004. Estradiol and its membraneimpermeable conjugate (estradiol-bovine 
seruma lbumin) during in vitro maturation of bovine oocytes: effects on nuclear and cytoplasmic maturation, cytoskeleton, and embryo quality. Biol. Repr., 70: 14651474

Anthony Sabasthin, Sumanta Nandi, Venkataswamy Girishkumar, Pavanashree, Ummadahalli Shankare Gowda and Virupakshaiah Chandrasekhar Murthy, 2013. Effect of sera of normal cycling, pregnant and repeat breeding buffaloes (Bubalus bubalis) on in vitro maturation of buffalo, sheep and goat oocytes. Asian. Pac. J. Rep., 110-113

Ayoub, M. A. and Hunter, A. G., 1993. Inhibitory effect of bovine follicular fluid on in vitro maturation of bovine oocytes. J. Dairy. Sci., 76: 95-100

Balain, D.S., 1999. Inflow and outflow of buffalo germplasm resources and their global contribution. Invited papers presented in short course on "characterization and conservation of domesticated livestock and poultry resources". 10-19 May, 1999, National Bureau of Animal Genetic Resources (ICAR), Karnal.

Beker, A.R.C.L., Colenbrander, B. and Bevers, M.M., 2002. Effect of 17- $\beta$ estradiol on the in vitro maturation of bovine oocytes. Theriogenology., 58(9): 1663-1673

Brevini, T., Cilio, F., Antonini, S., Tosetti, V. and Gandolfi, F., 2007.Temporal control of gene expression in early embryos of farm animals. Rep. Fertl. Dev., 19: 35-42

Department of Animal Husbandry, Dairying and Fisheries. 2014. Basic animal husbandry and fisheries statistics. Ministry of agriculture Krishibhawan, New Delhi

Elkhadrawy, H.H., Hammam, A.M., AbdelNaseer A.M., EL- Gendy. and AMAL, H. ALI., 2014. Effect of addition of buffalo FSH pituitary extract on maturation of buffalo oocytes (Bubalus bubalis) in vitro.
Glob. J. Pharma., 8 (4): 673-680

Eppig, J. J. and Sumi L. Koide., 1978.Effects of progesterone and oestradiol-17 $\beta$ on the spontaneous meiotic maturation of mouse oocytes. J. Reprod. Fert., 53: 99-101

Eppig, J., 1996. Coordination of nuclear and cytoplasmic oocyte maturation in eutherian mammals. Boil. Reprd., 41: 268-276

Fukui, Y., Fukushima, M., Terawaki, Y. and ONO, H., 1982. Effect of gonadotropins, steroids and culture media on bovine oocyte maturation in vitro. Theriogenology., 18(2):161-175

Gilchrist., Robert, B., Jeremy, G. and Thompson., 2007. Oocyte maturation: Emerging concepts and technologies to improve developmental potential in vitro. Theriogenology., 67: 6-15

Kaikini, A.S., 1992. Dimensions of infertility or sterility in cattle and buffaloes. Indian J. Anim.Reprod., 13: 10

Kaji, E., Bornslaeger, E.A. and Schultz RmJ, 1987. Inhibition of mouse oocyte cyclic AMP phosphodiesterase by steroid hormones: a possible mechanism for steroid hormone inhibition of oocyte maturation. Exp. Zool., 243(3): 489-93

Keniji Momozawa. and Yoshiri Fukuda., 2010. Effects of fractions of bovine follicular fluid and fetal bovine serum as supplements to maturation medium on in vitro development of in vitro fertilized embryo. J. Mamm. Ova. Res., 28: 68-74

Mahmoud, G.M. and Nawito, M.F., 2003. Cytogenetic evaluation of in vitro matured buffalo oocytes in different culture condition. Egypt. J. Vet. Sci., 37: 105-116

Mahmoud, K.G.H.M. and AL-Shimaa AL-H. H. EL-Naby., 2013. Factors affecting buffalo oocytes maturation. Glob. Vet., 11(5): 497-510

Mamy Khandoker., Reza, M.M.T., Asad, L.Y., Saha, S., Apu, A.S. and Sam Hoque., 2012. In vitro maturation of buffalo oocytes and fertilization by cattle 
spermatozoa. Bang. J. Anim. Sci., 41(1): 6-12

Mattioli, M., Bacci, M.L., Galeati. G. and Seren, E., 1991. Effects of LH and FSH on the maturation of pig oocytes in vitro.Theriogenology.,36(1):95-105

Mcgaughey, R.W., 1977.The culture of pig oocytes in minimal medium, and the influence of progesterone and estradiol17 beta on meiotic maturation. Endocrinology., 100(1): 39-45.

Momena Khatun., Mohammad Musharraf Uddin Bhuiyan., Jalal Uddin Ahmed., Aminul Haque., Mohammad Bozlur Rahman. and Mohammed Shamsuddin., 2010. In vitro maturation and fertilization of prepubertal and pubertal black Bengal goat oocytes. J. Vet. Sci., 12(1): 75-82

Samad, H.A., Khan, I. Q., Rehman, N.U. and Ahman, N., 1998. The recovery, in vitro maturation and fertilization of Nili-Ravi buffalo follicular oocytes. Asian-Austr. J. Anim. Sci., 11(5): 491-497

Stephen M. Downs., Douglas, L. Coleman., Patricia, F., Ward-Bailey. and John J. Eppig., 1984. Hypoxanthine is the principal inhibitor of murine oocyte maturation in a low molecular weight fraction of porcine follicular fluid. Proc. Natl. Acad. Sci. USA., 82: 454-458

Totey, S.M., Daliri, M., Appa Rao, K.B.C., Pawshe, C.H., Taneja, M. and Chillar, R.S., 1996. Differential cleavage and developmental rates and their co relation with cell numbers and sex ratios in buffalo embryos generated in vitro.
Theriogenology., 39: 887-898

Totey, S.M., Singh, G., Taneja, M., Pawshe, C.H. and Talwar, G.P., 1992. In vitro maturation, fertilization and development of follicular oocytes from buffalo (Bubalus bubalis). J.Reprod.Fertil., 95(2): 597-607

Tsafriri, A., Cao, X., Ashkenazi, H., Motola, S., Popliker, M. and Pomerantz, S.H., 2005. Resumption of oocyte meiosis in mammals: On models, meiosis activating sterols, steroids and EGF-like factors. Mol. Cel. End., 23(4):37-45

Uma Devi, S., 1997. Influence of various sera and hormone supplementation on in vitro maturation of buffalo oocytes. Thesis submitted to Dept. of Vet. Gyna. Obst. Veterinary College Bangalore.

Walker, S.K., Hiu, J.L., Bee, C.A. and Warner, D.M., 1994.Improving the rate of production of sheep embryos using in vitro maturation and fertilization. Theriogenology., 41:330

Wataru Tarumi., Masanori, T., ITOH and Nao Suzuki., 2014. Effects of 5adihydrotestosterone and $17 \beta$-estradiol on the mouse ovarian follicle development and oocyte maturation. PLoS.ONE., 9(6): $1-7$

Zheng-Guang Wang., Song-Dong YU. And ZI-Rong XU., 2007. Effects of collection methods on recovery efficiency, maturation rate and subsequent embryonic developmental competence of oocytes in Holstein cow. Asian-Aust. J. Anim. Sci., 20(4):

\section{How to cite this article:}

Ambadas, G. Sarvadnya, K. Shrikant and Satish, K. B. 2020. The Effect of Different Supplements to in vitro Maturation Medium on Nuclear Maturation Rate of Buffalo Oocytes Assessed based on Stage of Nucleus. Int.J.Curr.Microbiol.App.Sci. 9(02): 2059-2071. doi: https://doi.org/10.20546/ijcmas.2020.902.234 